\title{
Spanish Heart Transplantation Registry: 27th Official Report of the Spanish Society of Cardiology Working Group on Heart Failure and Heart Transplantation (1984-2015)
}

\author{
Registro Español de Trasplante Cardiaco: XXVII Informe Oficial de la Sección de \\ Insuficiencia Cardiaca y Trasplante Cardiaco de la Sociedad Española de \\ Cardiología (1984-2015)
}

Francisco González-Vílchez ${ }^{\mathrm{a}, \mathrm{b}}$, Javier Segovia Cubero ${ }^{\mathrm{c}}$, Luis Almenar ${ }^{\mathrm{d}}$, María G. Crespo-Leiro ${ }^{\mathrm{e}}$, José M. Arizón ${ }^{\mathrm{f}}$, Iago Sousa ${ }^{\mathrm{g}}$, Juan Delgado ${ }^{\mathrm{h}}$, Eulalia Roigi, José Manuel Sobrino ${ }^{\mathrm{j}}$, José González-Costello ${ }^{\mathrm{k}}$, on behalf of the Spanish Heart Transplant Teams

\footnotetext{
${ }^{a}$ Registro Español de Trasplante Cardiaco, Sección de Insuficiencia Cardiaca y Trasplante Cardiaco, Sociedad Española de Cardiología, Madrid, Spain

${ }^{b}$ Servicio de Cardiología, Hospital Universitario Marqués de Valdecilla, Instituto de Investigación Marqués de Valdecilla (IDIVAL), Santander, Cantabria, Spain

${ }^{c}$ Servicio de Cardiología, Clínica Puerta de Hierro, Majadahonda, Madrid, Spain

${ }^{d}$ Servicio de Cardiología, Hospital Universitario y Politécnico La Fe, Valencia, Spain

${ }^{e}$ Instituto de Investigación Biomédica de A Coruña (INIBIC), Complexo Hospitalario Universitario de A

Coruña (CHUAC), SERGAS, Universidade da Coruña (UDC), A Coruña, Spain

${ }^{f}$ Servicio de Cardiología, Hospital Universitario Reina Sofía, Córdoba, Spain

${ }^{g}$ Servicio de Cardiología (Adultos), Hospital Universitario Gregorio Marañón, Madrid, Spain

${ }^{h}$ Hospital Universitario 12 de Octubre, Madrid, Spain

${ }^{i}$ Hospital Universitario de la Santa Creu i Sant Pau, Barcelona, Spain

${ }^{j}$ Hospital Universitario Virgen del Rocío, Sevilla, Spain

${ }^{k}$ Hospital Universitario de Bellvitge, L'Hospitalet de Llobregat, Barcelona, Spain
}

\begin{abstract}
Introduction and objectives.

The present article reports the characteristics and results of heart transplants in Spain since this therapeutic modality was first used in May 1984.

Methods

We describe the main features of recipients, donors, surgical procedures, and results of all heart transplants performed in Spain until December 31, 2015.

Results

A total of 299 cardiac transplants were performed in 2015, with the whole series comprising 7588 procedures. The main transplant features in 2015 were similar to those observed in recent years. A remarkably high percentage of transplants were performed under emergency conditions and there was widespread use of circulatory assist devices, particularly continuous-flow left ventricular assist devices prior to transplant (16\% of all transplants). Survival has significantly improved in the last decade compared with previous time periods.

Conclusions

During the last few years, between 250 and 300 heart transplants have consistently been performed each year in Spain. Despite a more complex clinical context, survival has increased in recent years.
\end{abstract}




\section{Resumen}

Introducción y objetivos.

Se presentan las características y los resultados del trasplante cardiaco en España desde que empezó su actividad en mayo de 1984.

Métodos.

Se realiza un análisis descriptivo de las características de los receptores, los donantes, los procedimientos quirúrgicos y los resultados de los trasplantes cardiacos realizados en España hasta el 31 de diciembre de 2015.

Resultados.

Durante 2015 se han realizado 299 procedimientos, con lo que la serie histórica consta de 7.588 trasplantes. Las características generales del procedimiento son similares a las observadas en los últimos años y destacan el alto porcentaje de procedimientos realizados en código urgente y, sobre todo, la extensión del uso de dispositivos de asistencia circulatoria, particularmente la asistencia ventricular de flujo continuo (el 16\% del total de trasplantes). La supervivencia ha aumentado significativamente en la última década con respecto a periodos anteriores.

Conclusiones.

La actividad de trasplante cardiaco en España permanece estable en los últimos años, con alrededor de 250300 procedimientos al año. A pesar de la mayor complejidad del contexto clínico, se observa una mejora de la supervivencia en los últimos años.

\section{Keywords}

Heart transplantation; Registry; Survival

\section{Palabras clave}

Trasplante cardiaco; Registro; Supervivencia

\section{Abbreviations}

ECMO, extracorporeal membrane oxygenation; RETC, Spanish Heart Transplantation Registry (Registro Español de Trasplante Cardiaco) 


\section{INTRODUCTION}

Since 1991, the Spanish Heart Transplantation Registry (Registro Español de Trasplante Cardiaco [RETC] ) has published an annual description of the clinical and surgical characteristics and general results of all heart transplant procedures performed in Spain ${ }^{1-26}$. The current article reports data on the transplant population until 31 December 2015. As is already well-known, the main strength of the RETC lies in its inclusion and comprehensive updating of all heart transplant procedures performed in all Spanish hospitals since May 1984, regardless of the procedural characteristics and results. In addition, data collection is prospectively performed using a shared database developed and updated by all transplant teams.

\section{METHODS}

\section{Patients and Centers}

Of the 19 centers that have contributed data to the RETC, 18 are currently active (Table 1). Two centers are entirely dedicated to pediatric transplantation while another 3 perform both pediatric and adult transplantation. The numbers of procedures performed annually are summarized in Figure 1. The whole series comprises 7588 procedures. Data were lost on 12 patients, including follow-up information. These patients have been omitted from the analysis, giving a final sample size of 7576 patients. Of the 299 procedures performed in 2015, $22(7.4 \%)$ were performed in pediatric patients (age < 16 years). The types of procedures performed in 2015 and in the whole series are summarized in Table 2.

Table 1. Centers (by Order of First Transplantation Performed) Participating in the Spanish Heart Transplantation Registry (1984-2015)

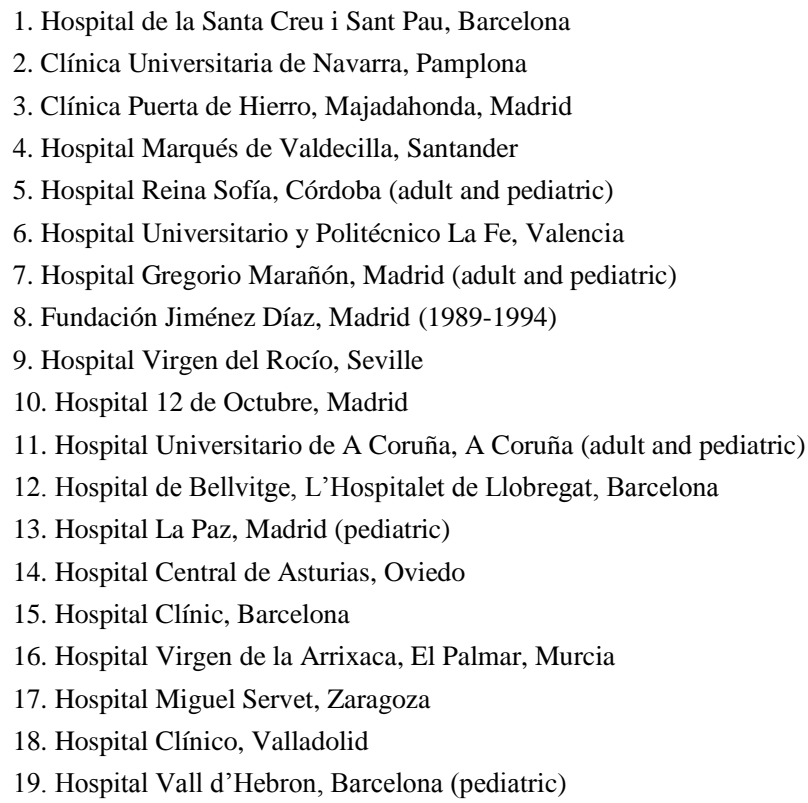




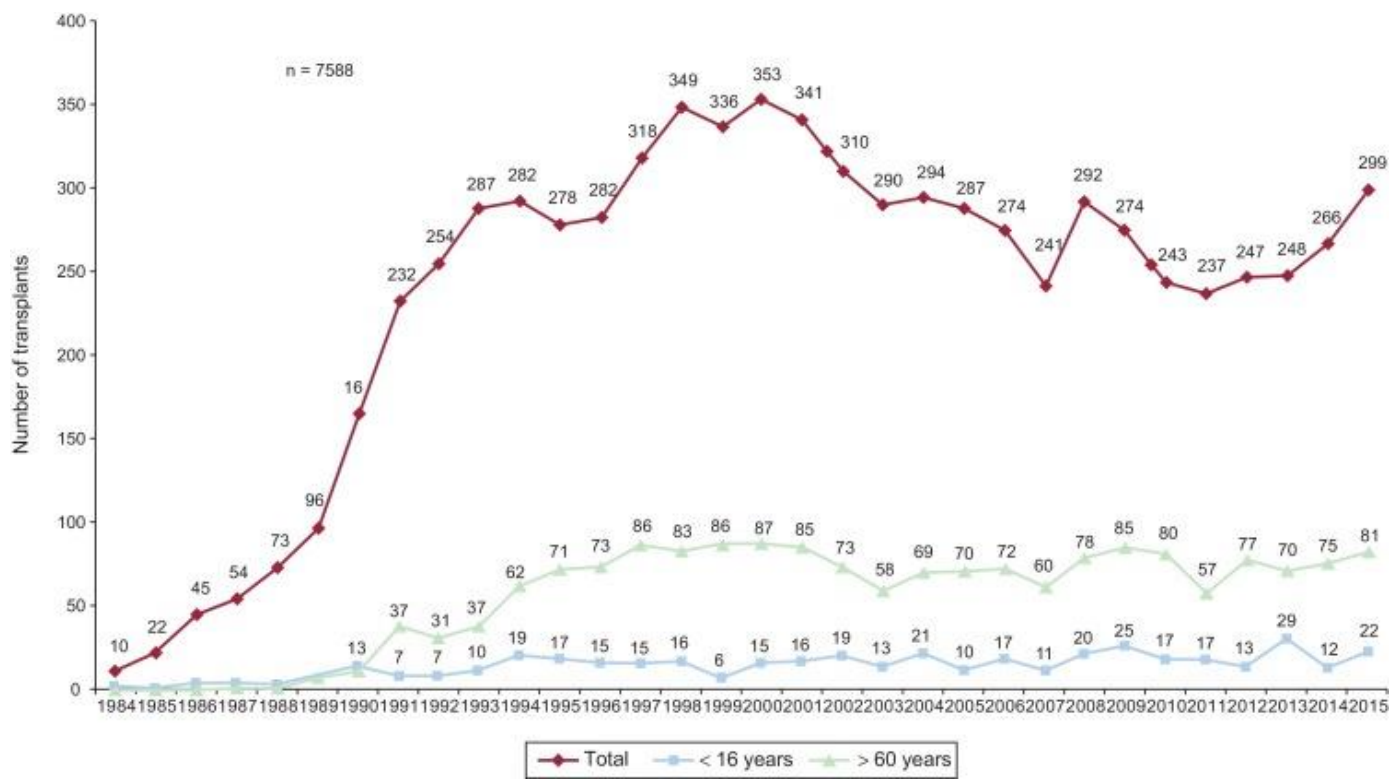

Figure 1. Annual number of transplants (1984-2015), total and by age group.

Table 2. Spanish Heart Transplantation Registry (1984-2015). Type of Procedure

\begin{tabular}{lcc}
\hline Procedure & 2015 & $1984-2015$ \\
\hline & 292 & 7243 \\
De novo heart transplants & 4 & 183 \\
Retransplants & 0 & $6^{\mathrm{a}}$ \\
Combined retransplants & 3 & 150 \\
Combined transplants & 2 & 74 \\
Heart-lung & 1 & $67^{\mathrm{b}}$ \\
Heart-kidney & - & 9 \\
Heart-liver & 299 & 7576 \\
Total & & \\
& & \\
\hline
\end{tabular}

${ }^{a}$ All renal transplant recipients.

${ }^{\mathrm{b}}$ Includes heart retransplant recipients.

\section{Procedures}

The database comprises 175 clinical variables, established by consensus among all the teams, and records data on recipients, donors, surgical techniques, immunosuppression, and follow-up. Since 2013, the data have been electronically introduced and updated in real time using a webbased program specifically designed for this purpose. The database support is a Microsoft Excel file. This procedure replaces the previous method, in which each center sent data to the registry director in Microsoft Access file format via email. An external CRO (contract research organization), currently ODDS S.L., performed database maintenance, quality control, and statistical analysis. 
Ethics committee approval, auditing, and registration with the Ministry of Health were performed in accordance with the Spanish Organic Law on Data Protection 15/1999.

\section{Statistics}

Continuous quantitative variables are presented as mean \pm standard deviation; categorical variables are presented as percentages. The results are categorized according to the year of transplantation and the total sample has been divided into 4 time periods (1984-1993, 1994-2003, 2004-2013, and 2014-2015). Some variables were also analyzed according to the annual data from the whole series, such as donor age, emergency transplants, and ischemia time. Differences among groups were analyzed using a nonparametric test for temporal trends (Kendall $\tau$ ) for categorical variables and analysis of variance test with polynomial fit for continuous variables. Survival curves were calculated using the Kaplan-Meier test and were compared using a log rank test. A $P$ value $<.05$ was considered statistically significant.

\section{RESULTS}

\section{Recipient Characteristics}

In 2015 , the recipients had a mean age of $49.5 \pm 16.5$ years (range, $0.14-73$ years); $76 \%$ were men, with the following underlying diagnoses: ischemic cardiomyopathy $(21.4 \%)$, nonischemic dilated cardiomyopathy (30.4\%), valvular heart disease (4.0\%), and other etiologies (44.2\%). Recipient characteristics by transplant period are summarized in Table 3 . There were significant trends toward older recipients, female sex, atypical causes of underlying heart disease, and an increase in pretransplant conditions with known prognostic effects, such as insulin-dependent diabetes mellitus, infection, cardiac surgery, and mechanical ventilation prior to transplant. Although the difference was not statistically significant, the proportion of retransplants fell below $2 \%$ in $2014-2015$, comprising $2.4 \%$ of the total series. In contrast, there was a significant decrease in pretransplant values of pulmonary vascular resistance and an almost significant decrease in pretransplant severe renal dysfunction throughout the time series. 
Table 3. Recipient Characteristics in the Spanish Heart Transplantation Registry (1984-2015)

\begin{tabular}{|c|c|c|c|c|c|c|}
\hline & $\begin{array}{l}1984-1993 \\
(\mathrm{n}=1230)\end{array}$ & $\begin{array}{l}1994-2003 \\
(\mathrm{n}=3148)\end{array}$ & $\begin{array}{l}2004-2013 \\
(\mathrm{n}=2633)\end{array}$ & $\begin{array}{l}2014-2015 \\
(n=565)\end{array}$ & $\begin{array}{c}P \\
\text { (trend) }\end{array}$ & $2015(\mathrm{n}=299)$ \\
\hline Age, $y$ & $46.7 \pm 13.4$ & $50.4 \pm 14.6$ & $49.5 \pm 16.5$ & $49.7 \pm 16.1$ & $<.001$ & $49.5 \pm 16.5$ \\
\hline$<16 \mathrm{y}$ & 3.9 & 4.8 & 6.8 & 6.0 & $<.001$ & 7.4 \\
\hline$>60 y$ & 10.0 & 24.3 & 27.3 & 27.6 & $<.001$ & 27.1 \\
\hline Men & 85.8 & 81.1 & 76.1 & 75.8 & $<.001$ & 76.3 \\
\hline$B M I$ & $24.2 \pm 4.0$ & $25 \pm 4.5$ & $24.9 \pm 4.7$ & $24.7 \pm 4.4$ & $<.001$ & $24.6 \pm 4.4$ \\
\hline Underlying etiology & & & & & $<.001$ & \\
\hline Nonischemic dilated & 40.8 & 37.8 & 37.5 & 37.9 & & 36.8 \\
\hline Ischemic & 40.2 & 43.7 & 36.5 & 38.1 & & 39.5 \\
\hline Valvular & 10.4 & 7.6 & 7.8 & 4.1 & & 3.7 \\
\hline Other & 8.6 & 10.8 & 18.1 & 20.0 & & 20.1 \\
\hline$P V R(W U)$ & $2.6 \pm 1.8$ & $2.3 \pm 1.8$ & $2.4 \pm 2.2$ & $2.2 \pm 1.3$ & $<.001$ & $2.2 \pm 1.4$ \\
\hline Creatinine $>2 \mathrm{mg} / \mathrm{dL}$ & 7.0 & 6.1 & 8.3 & 5.8 & .058 & 5.7 \\
\hline Bilirubin $>2 \mathrm{mg} / \mathrm{dL}$ & 19.7 & 17.8 & 18.2 & 16.4 & .436 & 16.0 \\
\hline Insulin-dependent diabetes & 8.5 & 12.9 & 17.0 & 23.9 & $<.001$ & 26.2 \\
\hline Moderate-severe COPD & 9.3 & 11.2 & 9.4 & 12.2 & .044 & 10.9 \\
\hline Previous infection & 4.0 & 9.4 & 13.7 & 12.7 & $<.001$ & 11.5 \\
\hline Previous cardiac surgery & 25.3 & 26.5 & 28.9 & 33.8 & .001 & 37.1 \\
\hline Heart retransplant & 2.8 & 2.1 & 2.6 & 1.8 & .84 & 1.3 \\
\hline $\begin{array}{l}\text { Mechanical ventilation } \\
\text { prior to transplant }\end{array}$ & 8.3 & 10.3 & 16.2 & 13.8 & $<.001$ & 15.7 \\
\hline Emergency transplant & 18.1 & 23.6 & 34.6 & 44.4 & $<.001$ & 47.2 \\
\hline
\end{tabular}

BMI, body mass index; COPD, chronic obstructive pulmonary disease; PVR, pulmonary vascular resistance.

The values in the Underlying etiology section were obtained from previous reports due to updating of the database and recoding of the various categories. Values expressed are percentages or mean \pm standard deviation.

Compared with 2014, there was a slight uptick in 2015 in emergency transplants, reaching almost half of all procedures. Thus, the use of emergency transplants has remained above $40 \%$ since 2013 (Figure 2). In 2015, there was another increase in the use of ventricular assist devices prior to transplantation, whose use was first recorded in $2009(P<.001)$ (Figure 3). Moreover, there was increased use of continuous-flow left ventricular assist devices (33.9\%) and reduction of almost one-half in the use of balloon pumps vs 2014 (Figure 4). 


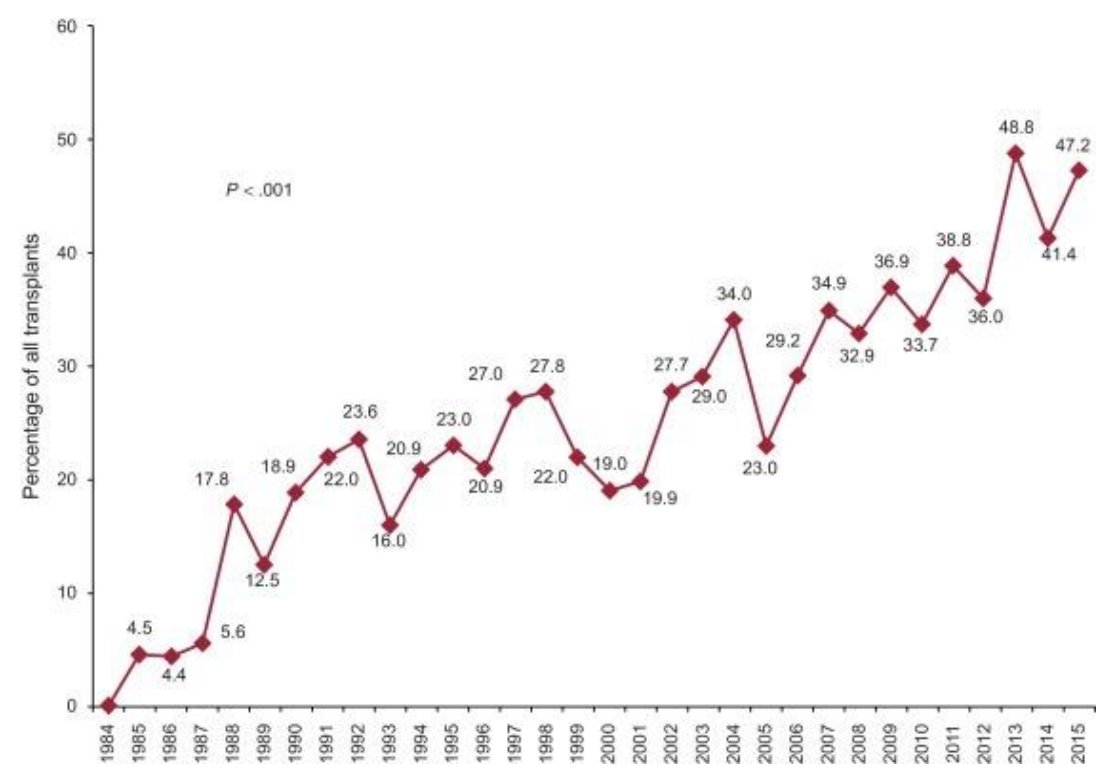

Figure 2. Annual percentage of emergency transplants among the total population (1984-2015).

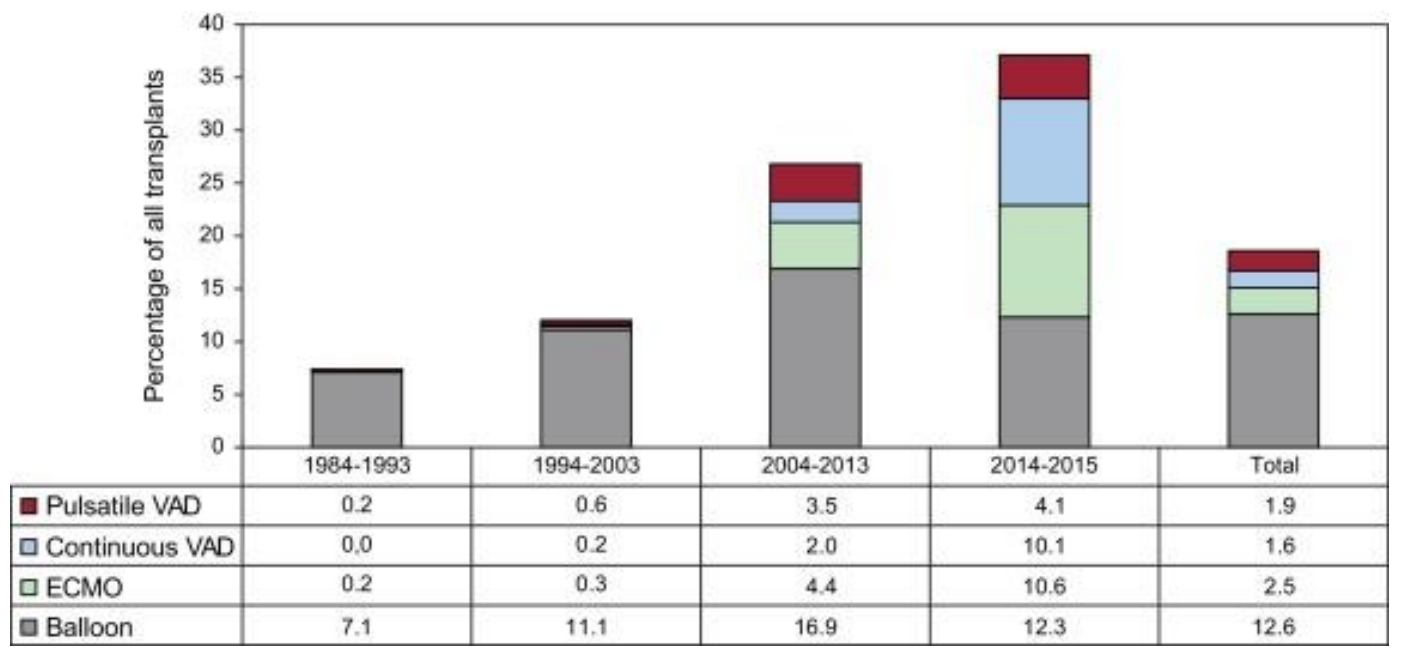

Figure 3. Distribution of the type of pretransplant circulatory support by time period (1984-2015). ECMO, extracorporeal membrane oxygenation; VAD, ventricular assist device. 


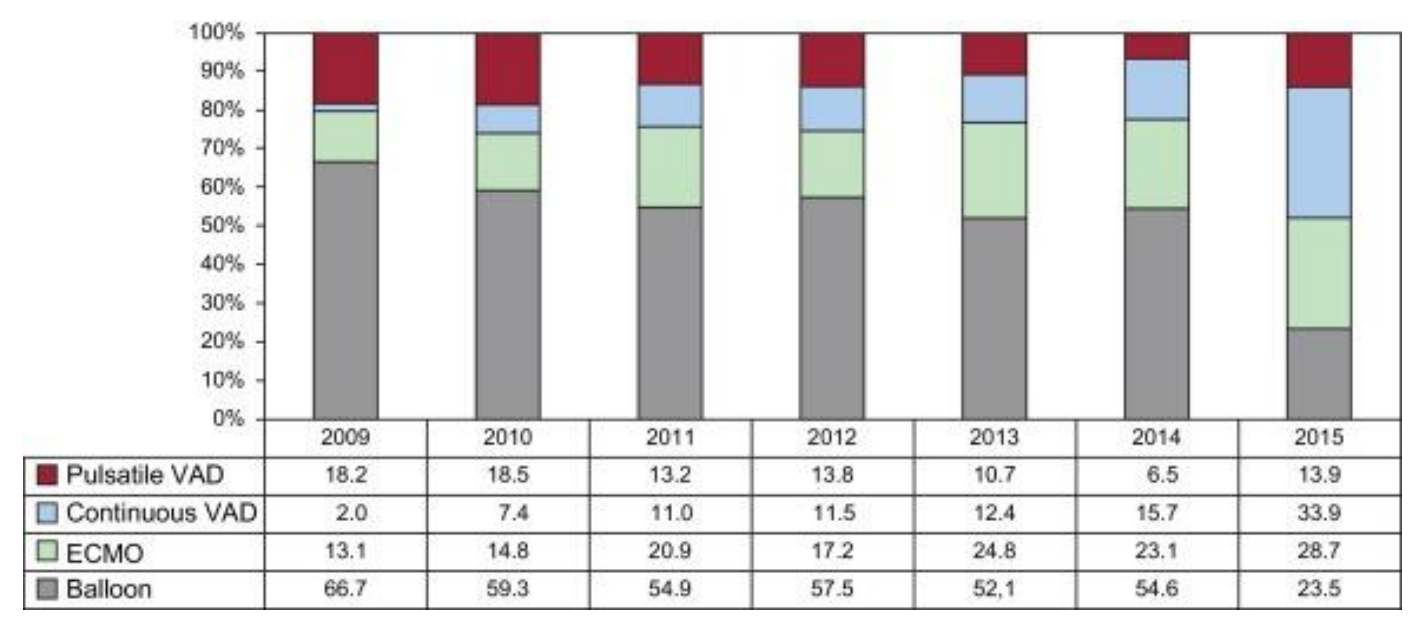

Figure 4. Distribution of the type of pretransplant circulatory support by year (2009-2015). ECMO, extracorporeal membrane oxygenation; VAD, ventricular assist device.

\section{Donor Characteristics and Ischemia Time}

The characteristics of the donors in 2015 and according to time interval are summarized in Table 4. Donor age has been significantly increasing throughout the series, with $55 \%$ of donors considered suboptimal (age > 45 years) in 2015 (Figure 5). There has been an increase in female donors and the percentage of female-to-male transplants $(26.4 \%)$, as well as cardiac arrest prior to donation (21.8\% in 2015). In addition, there was an increase in donors who died from stroke, with a consequent decrease in deaths from trauma (Figure 6). 
Table 4. Donor Characteristics and Ischemia Times in the Spanish Heart Transplantation Registry (1984-2015)

\begin{tabular}{|c|c|c|c|c|c|c|}
\hline & 1984-1993 & 1994-2003 & 2004-2013 & 2014-2015 & $P$ (trend) & 2015 \\
\hline & $(\mathrm{n}=1230)$ & $(\mathrm{n}=3148)$ & $(\mathrm{n}=2633)$ & $(\mathrm{n}=565)$ & & $(\mathrm{n}=299)$ \\
\hline Age, $y$ & $26.5 \pm 10.3$ & $31.3 \pm 12.9$ & $36.7 \pm 14.4$ & $43.3 \pm 14.5$ & $<.001$ & $43.1 \pm 14.2$ \\
\hline Age $>45 \mathrm{y}$ & 7.6 & 19.3 & 35.6 & 54.7 & $<.001$ & 55.5 \\
\hline Men & 78.4 & 70.9 & 66.1 & 59.8 & $<.001$ & 57.9 \\
\hline Female donor-male recipient & 17.8 & 20.9 & 21.1 & 24.8 & .008 & 26.4 \\
\hline Weight, $k g$ & $69.4 \pm 13.4$ & $70.1 \pm 16.1$ & $72.5 \pm 17.7$ & $74.4 \pm 18.3$ & $<.001$ & $73.8 \pm 18.3$ \\
\hline Recipient/donor weight & $1.0 \pm 0.2$ & 1. \pm 0.3 & $0.96 \pm 0.3$ & $0.97 \pm 0.6$ & $<.001$ & $0.94 \pm 0.2$ \\
\hline Recipient/donor weight $>1.20$ & 13.3 & 15.8 & 11.1 & 7.6 & $<.001$ & 6.0 \\
\hline Recipient/donor weight $<0.8$ & 13.8 & 14.7 & 19.5 & 20.2 & $<.001$ & 19.4 \\
\hline Cardiac arrest prior to transplant ${ }^{\mathrm{a}}$ & 3.0 & 7.2 & 10.1 & 19.8 & $<.001$ & 21.8 \\
\hline Predonation echocardiography ${ }^{\mathrm{b}}$ & & & & & $<.001$ & \\
\hline Not done & 52.5 & 21.0 & 5.3 & 1.1 & & 0.9 \\
\hline Normal & 47.1 & 77.7 & 92.2 & 96.2 & & 97.0 \\
\hline Mild generalized dysfunction & 0.3 & 1.2 & 2.5 & 2.7 & & 2.2 \\
\hline Ischemia time, $\min$ & $160.8 \pm 61.4$ & $184.8 \pm 61.7$ & $206.4 \pm 63.3$ & $199.2 \pm 71.7$ & $<.001$ & $199.0 \pm 71.0$ \\
\hline$<120 \mathrm{~min}$ & 27.0 & 18.0 & 11.2 & 15.0 & $<.001$ & 15.0 \\
\hline $120-180 \mathrm{~min}$ & 36.2 & 28.3 & 22.2 & 22.7 & & 22.7 \\
\hline $180-240 \mathrm{~min}$ & 28.1 & 36.7 & 39.0 & 36.3 & & 37.5 \\
\hline$>240 \mathrm{~min}$ & 8.7 & 17.1 & 27.6 & 26.0 & & 24.8 \\
\hline
\end{tabular}

Values expressed are percentages or mean \pm standard deviation.

${ }^{\text {a }}$ Of 4039 transplants.

${ }^{\mathrm{b}}$ Of 6361 transplants.

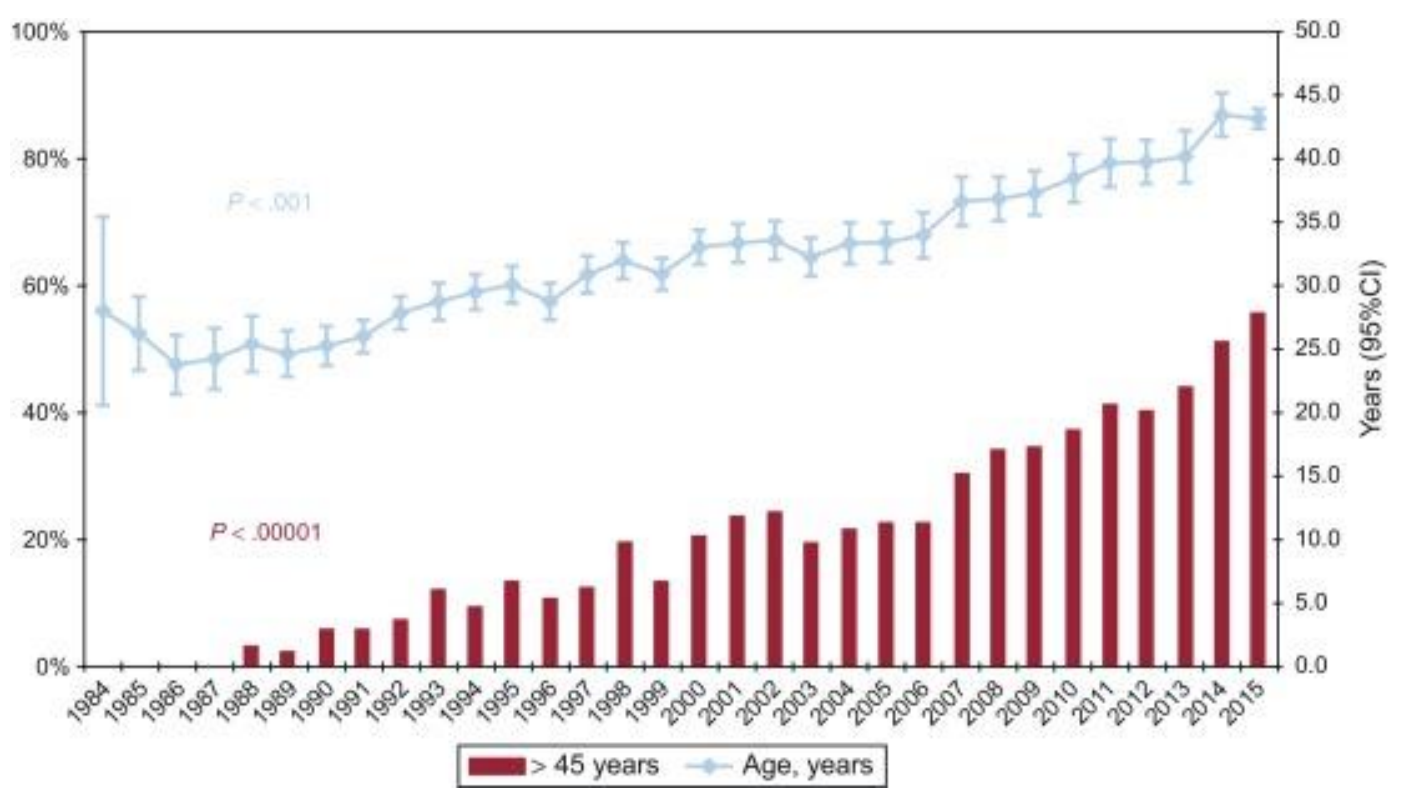

Figure 5. Annual changes in donor age and percentages of donors older than 45 years (1984-2015). 95\%CI, 95\% confidence interval. 


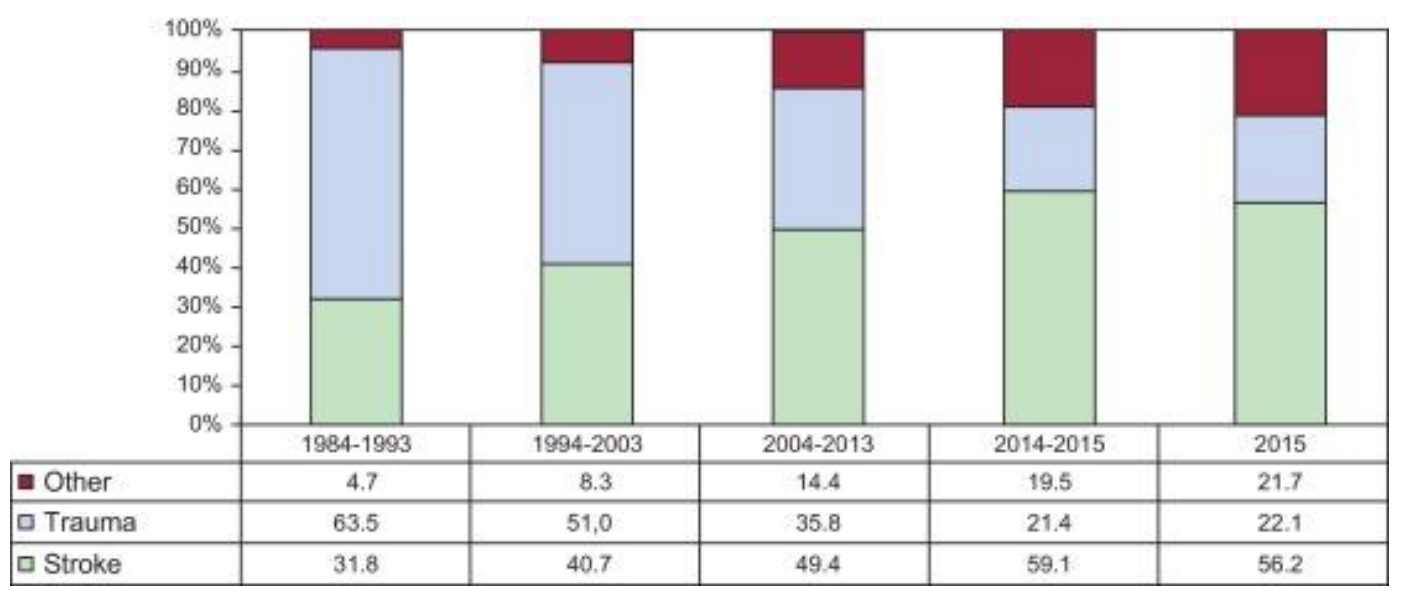

Figure 6. Changes by time period in the causes of death of heart donors.

Ischemia time has increased throughout the time series. In 2015 , as in the previous decade, the ischemia time was greater than $240 \mathrm{~min}$ in about a quarter of recipients (Table 4 and Figure 7).

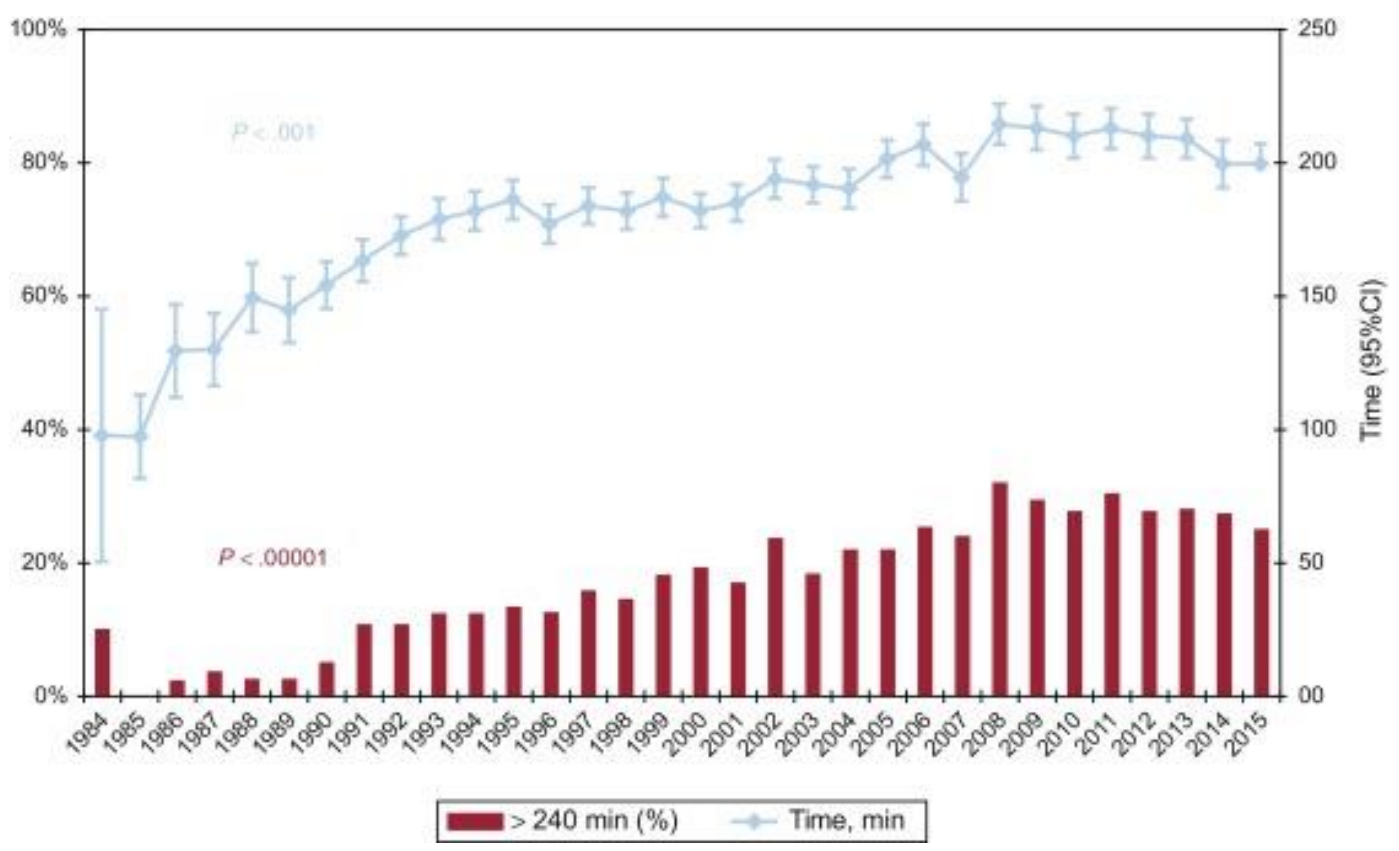

Figure 7. Annual changes in ischemia time and percentage with ischemia time $>240 \mathrm{~min}$ (1984-2015). 95\%CI, $95 \%$ confidence interval 


\section{Immunosuppression}

In $2015,83.4 \%$ of recipients received some type of induction immunosuppressive therapy, mainly involving basiliximab (79.1\%) (Figure 8), confirming the tendency observed since 2009.

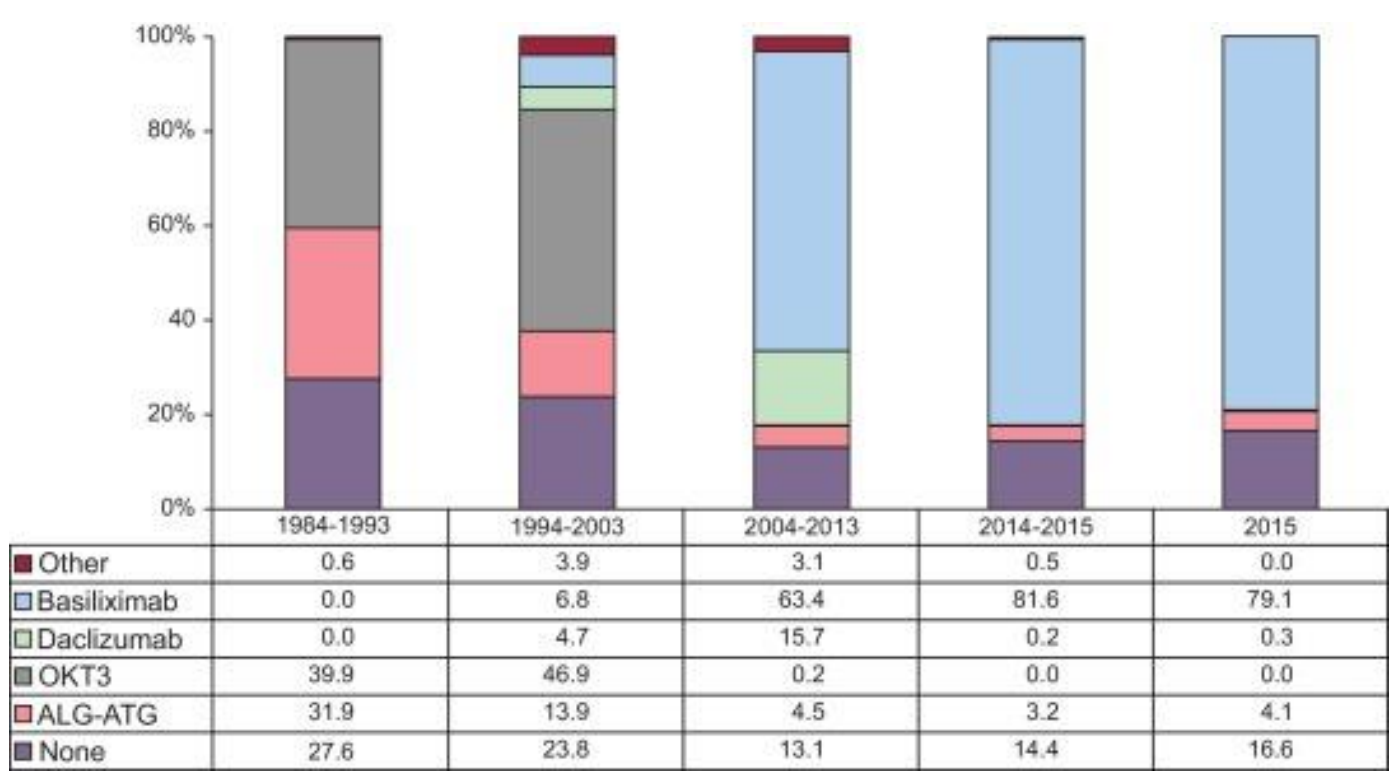

Figure 8. Drugs used in induction immunosuppression. ALG, antilymphocyte globulin; ATG, antithymocyte globulin.

The drugs used in the initial immunosuppression and at the end of follow-up for the whole series are summarized in Figure 9. In a mean follow-up of 7.2 years, $63.1 \%$ of patients continued to receive corticoid therapy. At last follow-up, $30 \%$ of patients were under treatment with mTor inhibitors (everolimus or sirolimus). 


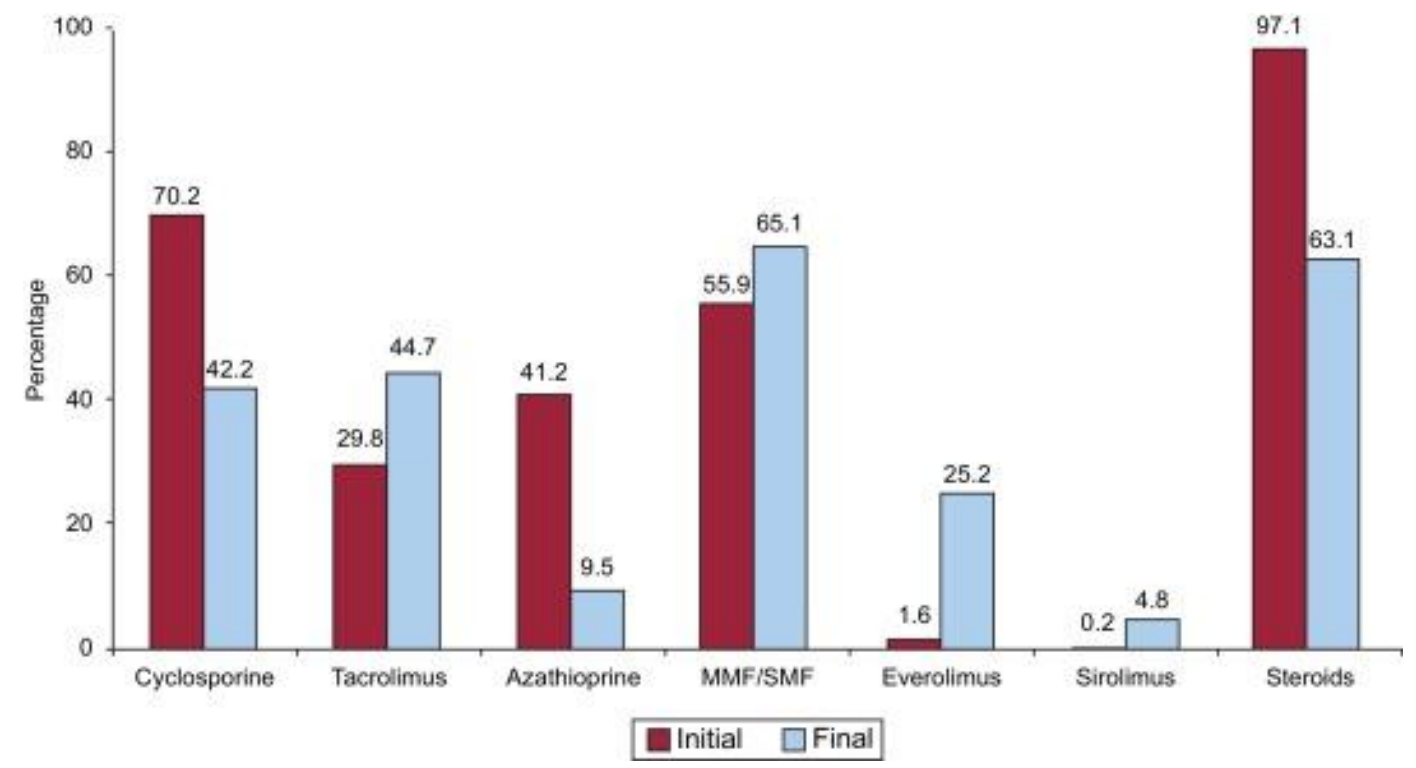

Figure 9. Initial and maintenance immunosuppression for the whole series (1984-2015). Progressive changes by type of drug: at time of transplant and at end of follow-up. MMF, mycophenolate mofetil; MPS, mycophenolate sodium.

In 2015, initial immunosuppression predominantly consisted of tacrolimus (89.3\%) as the calcineurin inhibitor, mycophenolate mofetil or mycophenolic acid (98.3\%) as the antiproliferative agent, and steroids (98.3\%). The annual changes in the use of the various calcineurin inhibitors and antimitotics are shown in Figure 10 and Figure 11, respectively. The annual changes in the use of the mTor inhibitors (sirolimus, everolimus) in the initial immunosuppression are shown in Figure 12.

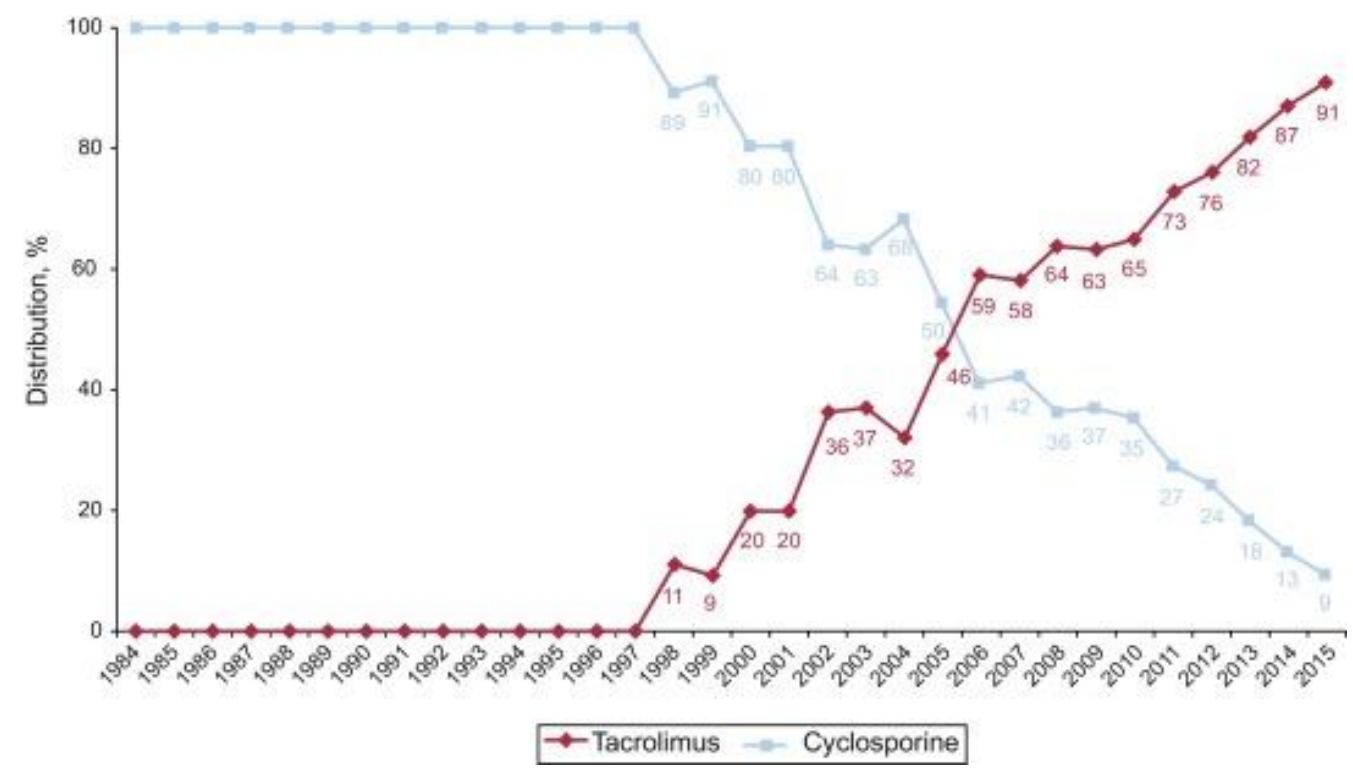

Figure 10. Annual changes in the use of calcineurin inhibitors (cyclosporine and tacrolimus) in initial immunosuppression in the total sample (1984-2015). 


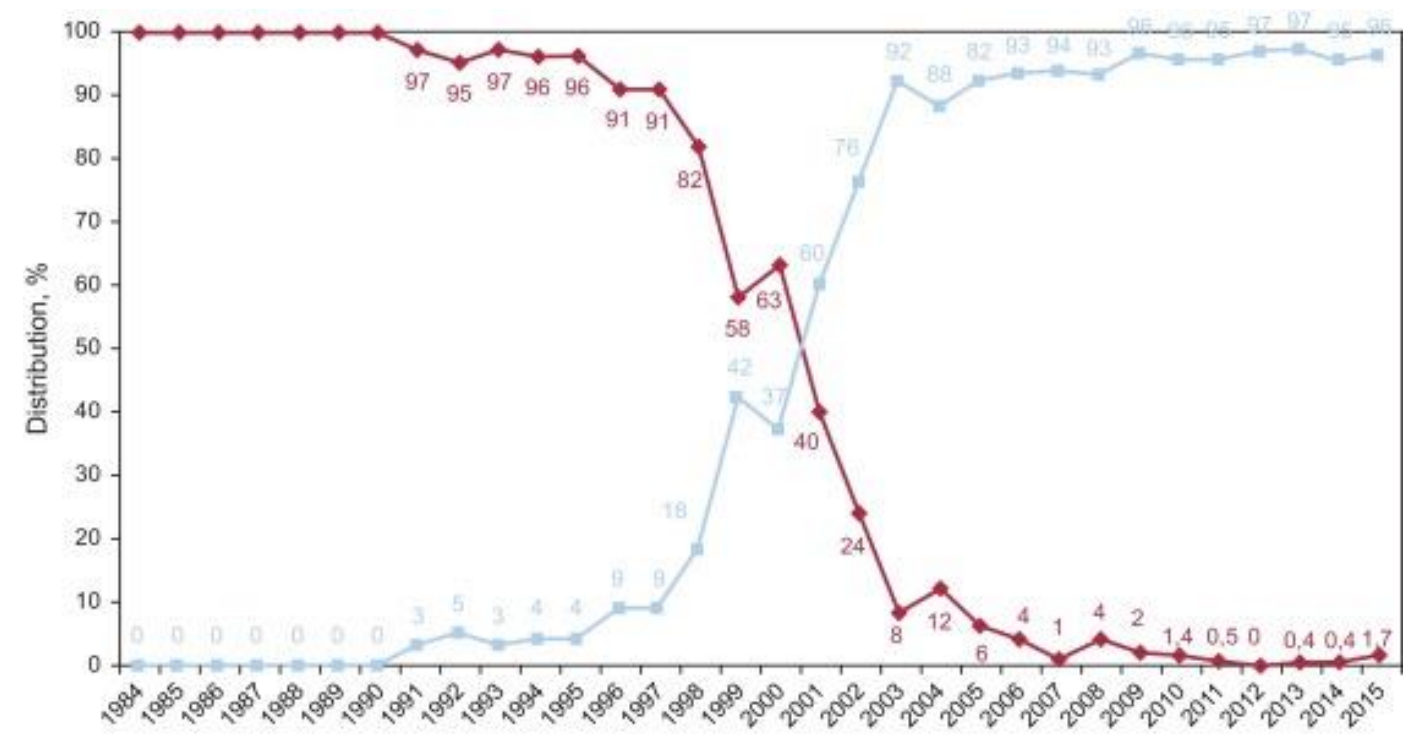

$\rightarrow$ Azathioprine $\rightarrow$ MMF/MMA

Figure 11. Annual changes in the use of antimitotics (azathioprine and mycophenolate mofetil/mycophenolic acid) in initial immunosuppression in the total sample (1984-2015). MMA, mycophenolic acid; MMF, mycophenolate mofetil.

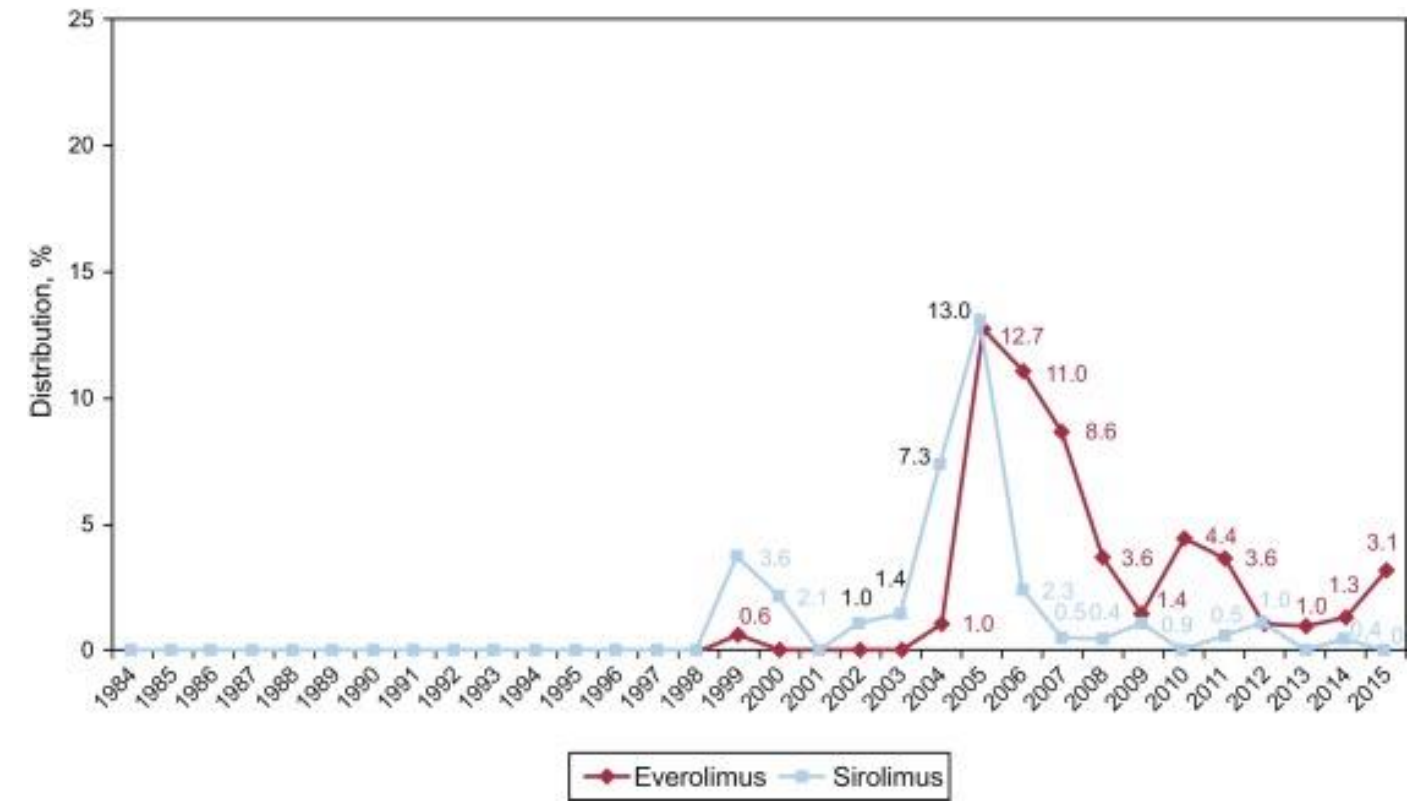

Figure 12. Annual changes in the use of mTor inhibitors (sirolimus and everolimus) in initial immunosuppression in the total sample (1984-2015). The unlabeled points have a value of 0 . 


\section{Survival}

With the most recent update from December 31, 2015, the 1-, 5-, 10-, 15-, and 20-year actuarial survivals in the entire time series are summarized in Figure 13. The survival curves indicate a mean annual mortality of about $2 \%$ to $3 \%$ after the first posttransplant year, with a median survival of 11.1 years. The 1-year conditional survival is shown in Figure 14. The conditional median survival after the first posttransplant year was 15.1 years. There were significant differences according to recipient age, donor age, type of procedure (isolated transplant, combined transplant, and retransplant), transplanturgency, and type of circulatory assistance at the time of transplant (without assistance, balloon pump, extracorporeal membrane oxygenation [ECMO], ventricular assist device). The most notable finding was the similar survival between elective transplants and transplants performed with balloon pump or ventricular assist devices. Transplants performed with prior ECMO showed significantly worse survival than those performed with no such device.

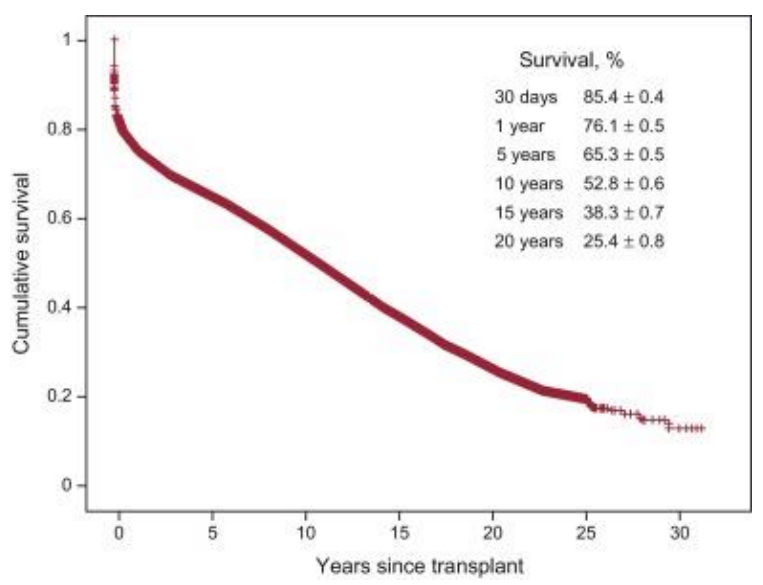

Figure 13. Overall survival curve for the whole series (1984-2015).

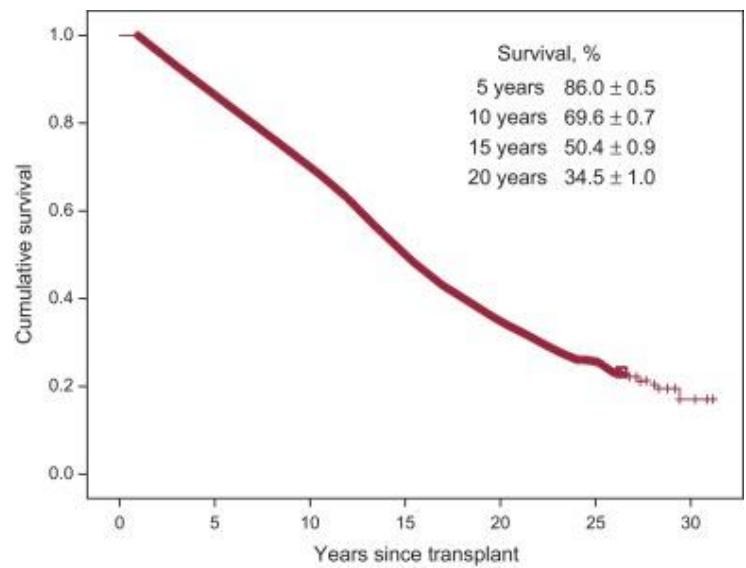

Figure 14. Survival curve conditioned on survival to the first year in the whole series (1984-2015). 
The survival results have constantly improved throughout the time series (Figure 15). Compared with the 1984 to 1993 decade, there were highly significant differences with the second decade and the period 2014 to 2015. Compared with the first decade, there was improved survival in the first posttransplant year in the following 2 decades. Compared with procedures performed between 1993 and 2013, there was an additional improvement in 1-year survival in 2014 and 2015 (Table 5). The improved survival in the 2004 to 2013 decade vs 1994 to 2014 was observed at a longer term (from the second posttransplant year) (Figure 15). The median survival improvement is continuous: 9.1 years (1984-1993), 10.9 years (1994-2003), and 12.0 years (2004-2013). In addition, the 2014 to 2015 period shows a clear tendency for improved survival vs the previous decade (2004-2013), even if this result is not statistically significant due to the relatively small sample size of the later group.

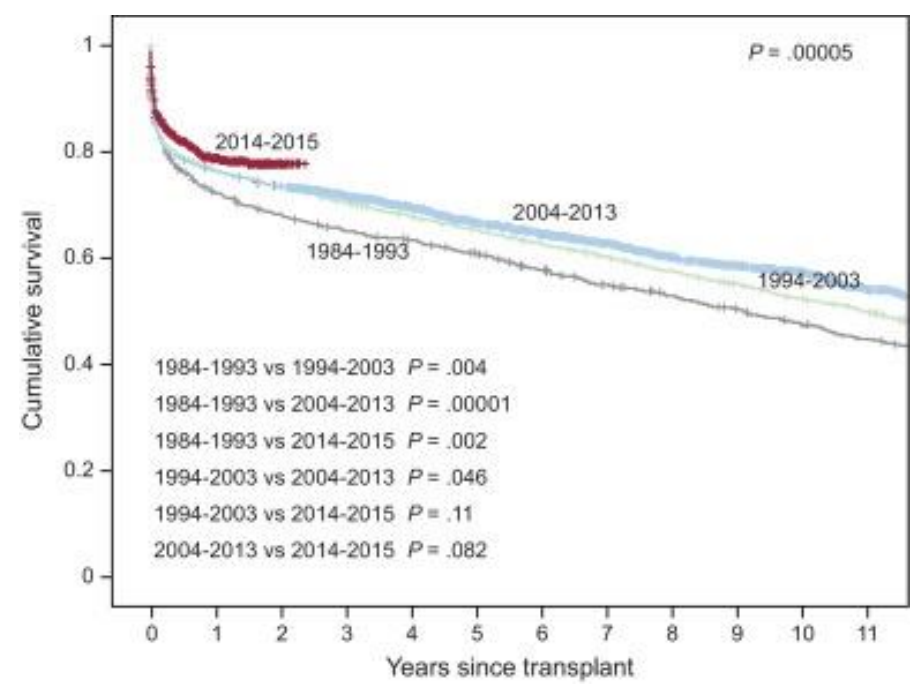

Figure 15. Survival curves by transplant period (10-year intervals, 1984-2013 and 2014-2015). 
Table 5. Univariable Survival Analysis by Baseline Characteristics of the Recipient, Donor, and Procedure (1984-2015)

\begin{tabular}{|c|c|c|c|}
\hline & HR $(95 \% \mathrm{CI})$ & $P$ & $\begin{array}{l}\text { Survival (y), median } \\
(95 \% \mathrm{CI})\end{array}$ \\
\hline \multicolumn{4}{|l|}{ Recipient age } \\
\hline$<16 \mathrm{y}$ & 1 & & $15.8(11.6-20.0)$ \\
\hline $16-60 y$ & $1.2(1.1-1.4)$ & .008 & $11.7(11.1-12.2)$ \\
\hline$>60 \mathrm{y}$ & $1.6(1.3-1.9)$ & $<.001$ & $8.6(7.8-9.4)$ \\
\hline \multicolumn{4}{|l|}{ Type of transplant } \\
\hline Isolated transplant & 1 & & $11.3(10.0-11.7)$ \\
\hline Combined transplant & $1.3(1.1-1.6)$ & .01 & $7.4(3.9-10.8)$ \\
\hline Retransplant & $1.7(1.4-2.1)$ & $<.001$ & $3.8(1.1-6.6)$ \\
\hline \multicolumn{4}{|l|}{ Donor age } \\
\hline$\leq 45 \mathrm{y}$ & 1 & & $11.6(11.1-12.1)$ \\
\hline$>45 \mathrm{y}$ & $1.2(1.1-1.3)$ & $<.001$ & $9.0(8.0-9.9)$ \\
\hline \multicolumn{4}{|l|}{ Procedure urgency } \\
\hline Elective & 1 & & $11.5(11.0-12.0)$ \\
\hline Emergency & $1.1(1.1-1.2)$ & $<.001$ & $9.8(8.6-10.9)$ \\
\hline \multicolumn{4}{|l|}{ Type of assistance ${ }^{*}$} \\
\hline Without assistance & 1 & & - \\
\hline Counterpulsation balloon & $1.2(0.9-1.2)$ & .13 & - \\
\hline ECMO & $1.6(1.2-2.1)$ & .003 & - \\
\hline Ventricular assistance & $0.9(0.7-1.3)$ & .77 & - \\
\hline
\end{tabular}

95\%CI, 95\% confidence interval; ECMO, extracorporeal membrane oxygenation; HR, hazard ratio.

* Patients transplanted between 2009 and 2015.

\section{Causes of Death}

In the total population, the most frequent cause of death was graft vascular disease/sudden death $(18.7 \%)$, followed by infections $(17.1 \%)$, primary graft failure $(13.6 \%)$, and neoplasia (13.1\%) (Figure 16). The causes of death depended on the time after transplant (Figure 16). In the first posttransplant month, almost $50 \%$ of deaths were due to primary graft failure. After the first month and until 1 year, acute rejection (15.3\%) and, above all, infections $(36.6 \%)$ were the main causes of death. After the first year, the main causes were various manifestations of graft vascular disease $(30.2 \%)$ and tumors $(22.0 \%)$. The main causes of death in the first year have changed significantly over time, with fewer deaths due to acute rejection and more deaths due to primary graft failure, even if the latter decreased in the 2014 to 2015 period (Figure 17). In deaths occurring between the first and fifth posttransplant years, there was a tendency for fewer deaths due to graft vascular disease/sudden death and significantly more deaths due to acute rejection (Figure 18). 


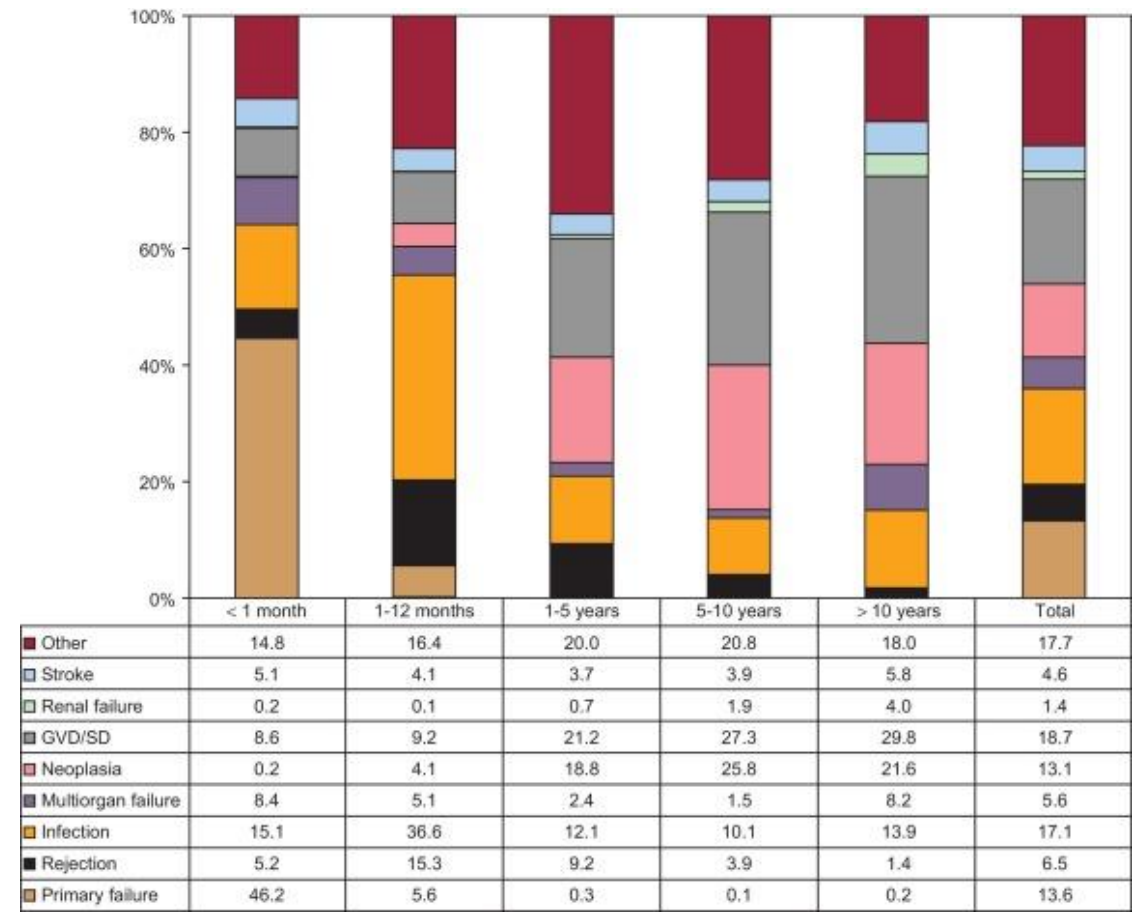

Figure 16. Causes of death by time from transplant and in the whole series (1984-2015). GVD, graft vascular disease; SD, sudden death.

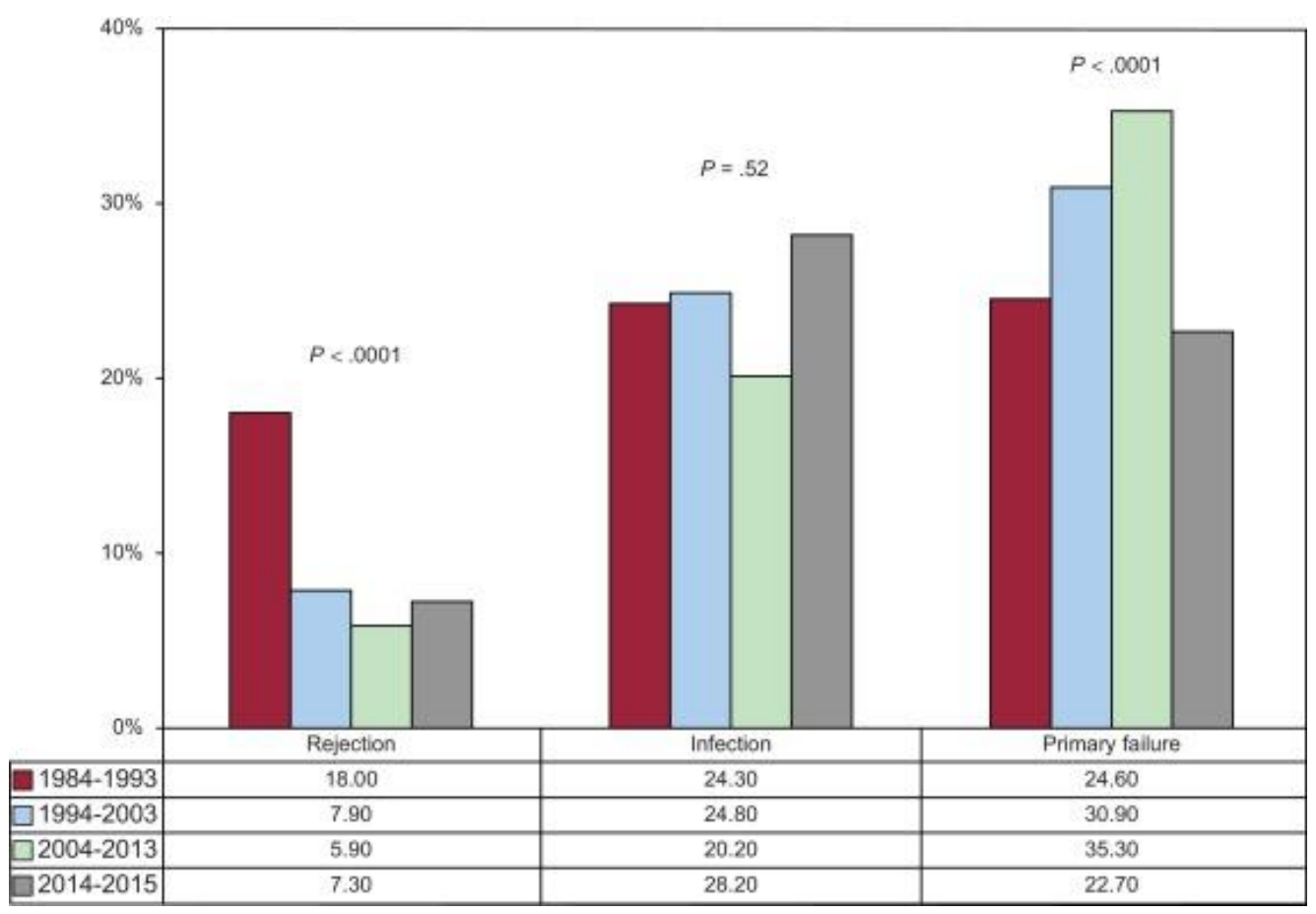

Figure 17. Main causes of death in the first posttransplant year in the whole series (1984-2015). 


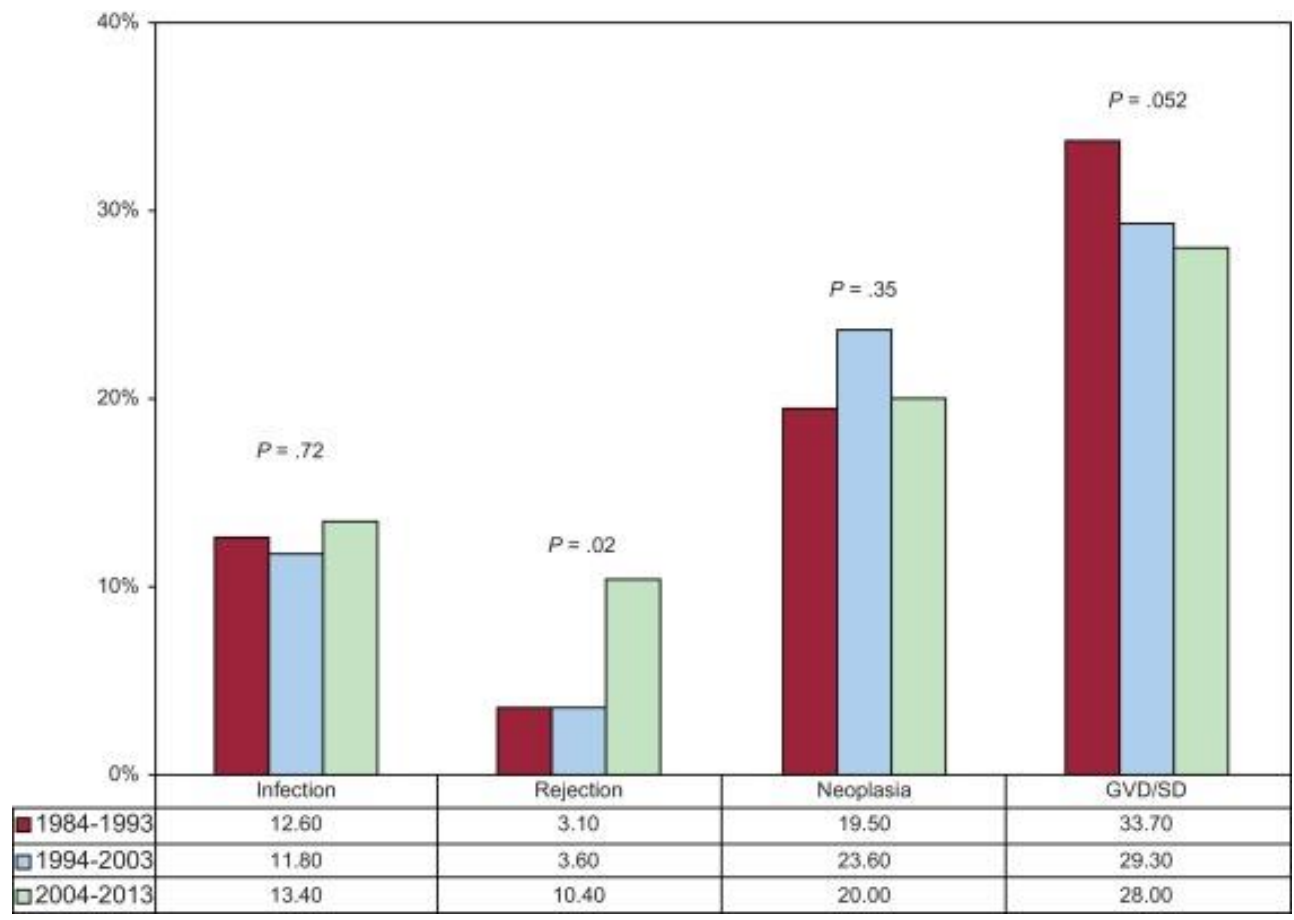

Figure 18. Main causes of death occurring between the first year and fifth posttransplant years in the whole series (1984-2015). GVD, graft vascular disease; SD, sudden death.

\section{DISCUSSION}

With the historical perspective provided by more than 30 years of RETC activity, with data on practically all heart transplant recipients in Spain, the most important finding of this registry is the change in the survival results. After the improved early survival in the second decade of activity (1994-2003), which was maintained in the subsequent decade (2004-2013), there has been an additional improvement in the last 2 years, with 1 -year survival rates close to $80 \%$. In addition, the improvement has been constant in the mid- to long-term, and it is hoped that this improvement will be maintained, given the tendency of the 2014 to 2015 curve. Both the values and the tendencies practically mirror those published by the registry of the International Society for Heart and Lung Transplantation for the 1982 to 2013 period $^{27}$. Nonetheless, despite including more than 100000 patients from the entire world, this registry has a selection bias, in contrast to the RETC, because information is not collected on all patients due to its voluntary nature.

The notable survival improvement in the RETC has been obtained in the context of growing recipient, donor, and surgical procedure complexity and has been maintained since about 2009 . Accordingly, the high percentage of transplants performed under emergency conditions (practically half of all procedures) is interesting, as well as the growing use of circulatory assist devices. In 2015, less than a quarter of all emergency transplants were performed with a balloon pump, a supportive measure that predominated until 2014. The use of ECMO prior to transplant has been largely stable since 2013, with a doubling in the use of continuous-flow left ventricular assist devices. Although the need for pretransplant circulatory support and the use of ECMO as a supportive measure increases early mortality, the prudent use of continuous-flow left ventricular assist devices and appropriate care of recipients receiving them is probably responsible for the decreased early mortality from primary graft failure. This factor would explain why the short- and 
mid-term survival is statistically similar for elective transplants and transplants performed with the prior use of these last devices.

Another interesting observation is that the improved survival in recent periods is not only due to improvements in early mortality (in the first year). Conditional survival curves show a separation from the second year, a trend that seems to be accentuated for patients transplanted in the last 2 years, although a longer clinical course is required to confirm this finding. The cause of this observation is undoubtedly multifactorial but there was a notable decrease in mid-term deaths due to graft vascular disease in more recent periods.

\section{CONCLUSIONS}

Heart transplant activity has been stable in Spain in recent years, with about 250 procedures per year. Despite the worsening of the current clinical setting and its growing complexity (eg, increased use of suboptimal donors and circulatory support), Spanish transplant teams have managed to maintain the mortality results and to progressively improve the mid-term prognosis.

\section{FUNDING}

The RETC is partially funded by an unconditional grant from Novartis.

\section{CONFLICTS OF INTEREST}

F. González-Vílchez receives remuneration for participating in the Comité de Control y Análisis Estadístico from Roche and Astellas, remuneration for educational presentations and travel expenses from Roche, Astellas, and Novartis, and unconditional support from the Instituto de Investigación Marqués de Valdecilla.

\section{Acknowledgments}

We appreciate the statistical support of ODDS, S.L. Many of the researchers and participating centers are part of the Red de Investigación Cardiovascular of the Instituto de Salud Carlos III. 


\section{APPENDIX. COLLABORATORS IN THE SPANISH HEART TRANSPLANTATION REGISTRY 1984-2015}

Clínica Universitaria Puerta de Hierro, Manuel Gómez-Bueno, Francisco Hernández-Pérez, Luis Alonso-Pulpón, Alberto Majadahonda, Madrid Forteza-Gil, Santiago Serrano-Fiz, Raúl Burgos-Lázaro, Carlos García-Montero, Evaristo Castedo-Mejuto

Hospital Universitario y Politécnico La Fe, Valencia

Ignacio Sánchez-Lázaro, Luis Martínez-Dolz, Mónica Cebrián-Pinar, Soledad Martínez-Penades

Hospital Universitario de A Coruña, A María J. Paniagua-Martin, Eduardo Barge-Caballero, Jose J. Cuenca-Castillo, Coruña Francisco Estevez-Cid, Gonzalo Barge-Caballero

Hospital Universitario Reina Sofía, Córdoba

Hospital Universitario Marqués de Valdecilla, Santander

Amador Lopez-Granados, Juan Carlos Castillo-Diéguez

Manuel Cobo, Miguel Llano-Cardenal, José A. Vázquez de Prada, Francisco Nistal-Herrera

Hospital Gregorio Marañón (adults), Madrid

Paula Navas, Eduardo-Zataraín, Juan Fernández-Yáñez, Adolfo-Villa, Manuel Martínez-Sellés

Hospital Universitario Doce de Miguel Ángel Gómez-Sánchez, Laura Morán-Fernández

Octubre, Madrid

Hospital de la Santa Creu i Sant Pau, Viçens Brossa, Sònia Mirabet, Laura López

Barcelona

Hospital Universitario Virgen del

Rocío, Seville

Hospital Universitario de Bellvitge, L'Hospitalet de Llobregat, Barcelona

Clínica Universitaria de Navarra, Cristian Delgado-Domínguez, Ignacio Bibiloni-Lage

Pamplona

Ernesto Lage-Gallé, Diego Rangel-Sousa

Nicolás Manito, Josep Roca-Elías, Joel Salazar-Mendiguchía

Hospital Clínic Universitari, Barcelona M. Ángeles Castel, Marta-Farrero, Ana García-Álvarez

Hospital Universitario Central de José Luis Lambert, Beatriz Díez de Molina, María José Bernardo-Rodríguez Asturias, Oviedo

Hospital Universitario Gregorio Manuela Camino, Constancio Medrano

Marañón (pediatric), Madrid

Hospital Universitario Virgen de la Domingo Pascual-Figal, Iris Garrido-Bravo, Francisco Pastor-Pérez

Arrixaca, Murcia

Hospital Universitario Miguel Servet, Teresa Blasco-Peiró, Marisa Sanz-Julvé, Ana Pórtoles-Ocampo

Zaragoza

Hospital Clínico Universitario, $\quad$ Luis de la Fuente-Galán, Javier López-Díaz, Ana María Correa Fernández Valladolid

Hospital Universitario La Paz, Madrid Luis García-Guereta, Luz Polo, Carlos Labrandero

Hospital Universitario Vall d'Hebron, Dimpna C. Albert-Brotons, Ferrán Gran-Ipiña, Raúl Abella

Barcelona

\section{References}

1. J.A. Vázquez de Prada. Registro Español de Trasplante Cardiaco. Primer Informe Oficial. Rev Esp Cardiol., 44 (1991), pp. 293-296.

2. J.A. Vázquez de Prada. Registro Español de Trasplante Cardiaco. Segundo Informe Oficial 1991. Rev Esp Cardiol., 45 (1992), pp. 5-8.

3. J.M. Arizón, J. Segura, M. Anguita, J.A. Vázquez de Prada. Registro Español de Trasplante Cardiaco. Tercer Informe Oficial. Rev Esp Cardiol., 45 (1992), pp. 618-621.

4. J.M. Arizón del Prado. Registro Español de Trasplante Cardiaco. Cuarto Informe Oficial (1984-1992). Rev Esp Cardiol., 46 (1993), pp. 791-795.

5. J.M. Arizón del Prado. Registro Español de Trasplante Cardiaco. Quinto Informe Oficial (1984-1993). Rev Esp Cardiol., 47 (1994), pp. 791-795.

6. J.M. Arizón del Prado. Registro Español de Trasplante Cardiaco. Sexto Informe Oficial (1984-1994). Rev Esp Cardiol., 48 (1995), pp. 792-797.

7. J.M. Arizón del Prado. Registro Español de Trasplante Cardiaco. Séptimo Informe Oficial (1984-1995). Rev Esp Cardiol., 49 (1996), pp. 781-787. 
8. J.M. Arizón del Prado. Registro Español de Trasplante Cardiaco. VIII Informe Oficial (1984-1996). Rev Esp Cardiol., 50 (1997), pp. 826-832.

9. L. Almenar Bonet. Registro Español de Trasplante Cardiaco. IX Informe Oficial (1984-1997). Rev Esp Cardiol., 52 (1999), pp. 152-158.

10. L. Almenar Bonet. Registro Español de Trasplante Cardiaco. X Informe Oficial (1984-1998). Rev Esp Cardiol., 52 (1999), pp. 1121-1129.

11. L. Almenar Bonet. Registro Español de Trasplante Cardiaco. XI Informe Oficial (1984-1999). Rev Esp Cardiol., 53 (2000), pp. 1639-1645.

12. L. Almenar Bonet. Registro Español de Trasplante Cardiaco. XII Informe Oficial (1984-2000). Rev Esp Cardiol., 54 (2001), pp. 1305-1310.

13. L. Almenar Bonet. Registro Español de Trasplante Cardiaco. XIII Informe Oficial (1984-2001). Rev Esp Cardiol., 55 (2002), pp. 1286-1292.

14. L. Almenar Bonet. Registro Español de Trasplante Cardiaco. XIV Informe Oficial (1984-2002). Rev Esp Cardiol., 56 (2003), pp. 1210-1217.

15. L. Almenar Bonet. Registro Español de Trasplante Cardiaco. XV Informe Oficial (1984-2003). Rev Esp Cardiol., 57 (2004), pp. 1197-1204.

16. L. Almenar Bonet. Registro Español de Trasplante Cardiaco. XVI Informe Oficial (1984-2004). Rev Esp Cardiol., 58 (2005), pp. 1310-1317.

17. L. Almenar Bonet. Registro Español de Trasplante Cardiaco. XVII Informe Oficial (1984-2005). Rev Esp Cardiol., 59 (2006), pp. 1283-1291.

18. L. Almenar Bonet. Registro Español de Trasplante Cardiaco. XVIII Informe Oficial de la Sección de Insuficiencia Cardiaca, Trasplante Cardiaco y Otras Alternativas terapéuticas de la Sociedad Española de Cardiología (1984-2006). Rev Esp Cardiol., 60 (2007), pp. 1177-1187.

19. L. Almenar Bonet. Registro Español de Trasplante Cardiaco. XIX Informe Oficial de la Sección de Insuficiencia Cardiaca, Trasplante Cardiaco y Otras Alternativas terapéuticas de la Sociedad Española de Cardiología (1984-2007). Rev Esp Cardiol., 61 (2008), pp. 1178-1190.

20. L. Almenar Bonet. Registro Español de Trasplante Cardiaco. XX Informe Oficial (1984-2008). Rev Esp Cardiol., 62 (2009), pp. 1286-1296.

21. L. Almenar, J. Segovia, M.G. Crespo-Leiro, J. Palomo, J.M. Arizón, F. González-Vílchez, et al. XXI Informe Oficial de la Sección de Insuficiencia Cardiaca y Trasplante Cardiaco de la Sociedad Española de Cardiología (1984-2009). Rev Esp Cardiol., 63 (2010), pp. 1317-1328.

22. L. Almenar, J. Segovia, M.G. Crespo-Leiro, J. Palomo, J.M. Arizón, M. Cobo, on behalf of the Equipos Españoles de Trasplante Cardiaco, et al.. Registro Español de Trasplante Cardiaco. XXII Informe Oficial de la Sección de Insuficiencia Cardiaca y Trasplante Cardiaco de la Sociedad Española de Cardiología (1984-2010). Rev Esp Cardiol., 64 (2011), pp. 1138-1146.

23. L. Almenar, J. Segovia, M.G. Crespo-Leiro, J. Palomo, J.M. Arizón, F. González-Vílchez, Registro Español de Trasplante Cardiaca. XXIII Informe Oficial de la Sección de Insuficiencia Cardiaca y Trasplante Cardiaco de la Sociedad Española de Cardiología (1984-2011). Rev Esp Cardiol., 65 (2012), pp. $1030-1038$.

24. F. González-Vílchez, M. Gómez-Bueno, L. Almenar, M.G. Crespo-Leiro, J.M. Arizón, M. MartínezSellés, Registro Español de Trasplante Cardiaco, et al. XXIV Informe Oficial de la Sección de Insuficiencia Cardiaca y Trasplante Cardiaco de la Sociedad Española de Cardiología (1984-2012). Rev Esp Cardiol., 66 (2013), pp. 973-982.

25. F. González-Vílchez, M. Gómez-Bueno, L. Almenar, M.G. Crespo-Leiro, J.M. Arizón, J. Palomo, Spanish Heart Transplantation Teams, et al. Spanish Heart Transplantation Registry. 25th official report of the Spanish Society of Cardiology Working Group on Heart Failure and Heart Transplantation (19842013). Rev Esp Cardiol., 67 (2014), pp. 1039-1051.

26. F. González-Vílchez, J. Segovia Cubero, L. Almenar, M.G. Crespo-Leiro, J.M. Arizón, A. Villa, Spanish Heart Transplantation Teams., et al. Spanish Heart Transplantation Registry. 26th Official Report of the Spanish Society of Cardiology Working Group on Heart Failure and Heart Transplantation (1984-2014). Rev Esp Cardiol., 68 (2015), pp. 1008-1021.

27. The International Society for Heart \& Lung Transplantation. Registries - Heart/Lung Registries. 2015 slides. Adult heart trasplantation statistics. Slide 43 [accessed 2016 Jul 10]. Available at: https://www.ishlt.org/registries/slides.asp?slides=heartLungRegistry. 